\title{
Pembentukan Komunitas Peduli Hipertensi dan DM Berbasis IPCP Di Sedayu Bantul
}

\author{
Wiwik Kusumawati ${ }^{1}$, Salmah Orbayinah ${ }^{2}$, dan Hari Widada ${ }^{3}$ \\ 1. Program Studi Pendidikan Dokter,Fakultas kedokteran dan Ilmu Kesehatan, Universitas Muhammadiyah Yogyakarta, J. Brawijaya \\ (Lingkar Selatan) Tamantirto, Kasihan, Bantul, Yogyakarta 55183 Telp. 0274387656 \\ Email: wiwik@umy.ac.id \\ DOI: $10.18196 / p p m .32 .180$
}

\begin{abstract}
Abstrak
Hipertensi adalah kondisi saat tekanan darah berada pada nilai 130/80 mmhg atau lebih. Diabetes Mellitus adalah peningkatan kadar glukosa darah lebih dari $126 \mathrm{mg} / \mathrm{dl}$ dalam kondisi puasa.Praktik kolaborasi memperkuat sistem dan memperbaiki hasil Kesehatan merupakan praktik kolaborasi dikenal dengan Interprofesional Collaboration Practice (IPCP), sedangkan proses pendidikannya disebut Interprofessional Education (IPE). FKIK UMY melaksanakan pembelajaran IPE di kampus dan praktik kolaborasinya di rumah sakit PKU Muhammadiyah Gamping. Tujuan dari program ini adalah meningkatkan pemahaman tentang hipertensi dan DM serta terbentuknya komunitas peduli hipertensi dan DM sehingga mampu meningkatkan mutu kesehatan dan kualitas hidup penderita hipertensi dan Diabetes Mellitus di Desa Argorejo Sedayu Bantul.Tahapan kegiatan meliputi prapelaksanaan, yaitu sosialisasi program, tahap pelaksanaan meliputi pemeriksaan tensi dan kadar gula darah, pembentukan komunitas peduli hipertensi dan diabetes mellitus, penyuluhan dan pelatihan mengukur tekanan dan kadar gula darah, tahap pascapelaksanaan meliputi evaluasi kegiatan dan keberlanjutan program. Peserta kegiatan berjumlah 48 orang dengan hasil terjadi peningkatan pemahaman, gaya hidup sehat, dan terbentuknya komunitas peduli hipertensi dan DM. Dari 48 peserta, 15 mempunyai tekanan darah tinggi, 1 orang mempunyai kadar gula darah tinggi, dan selebihnya normal. Komunitas peduli hipertensi dan DM yang telah terbentuk bersifat sosial dan mandiri.
\end{abstract}

Kata Kunci: Hipertensi, Diabetes Mellitus, Interprofessional Colaboration Practice

\section{Pendahuluan}

Hipertensi merupakan salah satu penyakit tidak menular yang saat ini masih menjadi masalah di Indonesia. Hipertensi menjadi berbahaya karena memiliki banyak komplikasi. Stroke, penyakit jantung, hingga gagal ginjal merupakan penyakit-penyakit katastropik yang tidak hanya memiliki angka kematian tinggi, tetapi juga membebani ekonomi keluarga.

Penyakit Diabetes Mellitus (DM) menjadi penyakit tidak menular peringkat ke dua setelah hipertensi. Dalam penanganan penyakit hipertensi dan Diabetes Mellitus (DM), kolaborasi antartenaga medis menjadi sangat penting untuk keberhasilan terapi pada pasien. Masyarakat awam masih banyak yang belum paham tentang praktik kolaborasi antarprofesi yang sebenarnya sangat menguntungkan pasien. Praktik ini akan memberikan pelayanan yang optimal terhadap pasien. Intervensi terhadap pasien tidak hanya dilakukan dari segi penyakit yang diderita, tetapi juga komunikasi kepada pasien. Setiap profesional dalam bidang kesehatan mempelajari peran masing-masing melalui proses pendidikan dari keprofesian dan disiplin ilmu.

Mitra dalam pelaksanaan program kegiatan ini adalah anggota Aisyiyah di Cabang Sedayu Argorejo, Bantul dan anggota PKK RT 56 Argorejo, Sedayu, Bantul. Masyarakat sekitar daerah tersebut belum pernah terpapar dan belum paham tentang praktik kolaborasi antarprofesi terkait penyakit hipertensi dan DM. Masyarakat peduli hipertensi dan DM yang tergabung dalam praktik IPC dipilih yang usianya $>40$ tahun. Dalam meningkatkan kualitas hidup penderita hipertensi dan DM diperlukan kolaborasi tenaga kesehatan sebagai salah satu cara untuk mendapatkan terapi yang optimal serta dapat mengontrol tensi dan kadar kadar glukosa darah bagi penderita DM. Hal-hal yang diperlukan adalah edukasi dan pemberian penyuluhan mengenai hipertensi dan DM. Penderita hipertensi diharapkan mampu mengetahui tekanan darahnya melalui pemeriksaan tensi penggunaan tensimeter. Penderita DM diharapkan mampu 
memeriksa kadar glukosa darahnya masing-masing menggunakan alat berupa KIT glukosa darah. Selain itu, perilaku hidup sehat juga harus diterapkan oleh penderita hipertensi dan penderita DM. Semua hal ini tidak terlepas dari peran tenaga kesehatan dalam meningkatkan kualitas pelayanan dan meningkatkan taraf hidup pasien.

\section{Metode Pelaksanaan}

Pengabdian masyarakat diawali dengan membuat diagnosis permasalahan di desa mitra. Adapun hasil diagnosisnya antara lain

1. Kesadaran masyarakat yang masih rendah terhadap pentingnya perawatan yang komprehensif pada penyakit hipertensi dan DM.

2. Ketidaktahuan masyarakat terhadap berbagai cara mencegah dan mengatasi penyakit hipertensi dan DM.

3. Belum ada komunitas peduli hipertensi dan DM berbasis pelayanan atau praktik Interprofessional Collaboration

4. Masih rendahnya gaya hidup sehat pada pasien hipertensi dan DM.

Tim PM yang terlibat dari Prodi Kesehatan FKIK UMY dan responden adalah komunitas peduli hipertensi dan DM.

Adapun tahap pelaksanaan pengabdian masyarakat sebagai berikut :

1. Tahap prapelaksanaan meliputi sosialisasi program ke masyarakatt setempat. Sebelumnya, tim sudah membuat yang berisi materi yang dijelaskan dan dibagikan ketika sosialisasi.

2. Tahap pelaksanaan meliputi senam kesehatan kolaborasi hipertensi dan DM, pemeriksaan tensi dan kadar gula darah, pembentukan komunitas peduli hipertensi dan DM, penyuluhan dan pelatihan mengukur tekanan darah dan mengukur kadar gula dalam darah.

3. Tahap pascapelaksanaan meliputi evaluasi kegiatan dan keberlanjutan program. Untuk evaluasi, akan dibuat pertanyaan seputar hipertensi dan DM sebelum dan sesudah pelaksanaan.

Hasil dari pengabdian masyarakat ini adalah terbentuk komunitas peduli hipertensi dan DM yang cerdas, mampu mengukur tensi dan mengukur kadar gula darah secara mandiri, dan menerapkan pola gaya hidup sehat.

\section{Hasil dan Pembahasan}

Kegiatan penyuluhan dan pelatihan mengukur tekanan darah dan mengukur kadar gula dalam darah telah dilaksanakan pada hari Selasa, 26 Maret 2019. Kegiatan diikuti oleh anggota Aisyiyah Cabang Sedayu dan masyarakat sekitarnya yang berjumlah 48 peserta. Penyuluhan didahului dengan penjelasan mengenai pentingnya IPE dan IPCP dalam pendidikan Profesi Kesehatan, diikuti penjelasan tentang penyakit hipertensi beserta penyebabnya, dan cara mengatasi penyakit DM.

Pelayanan kesehatan selama ini masih belum dapat berkolaborasi dan bekerja sama dengan baik sehingga hasil yang didapat belum optimal dan harus mengeluarkan biaya yang tidak sedikit. Dalam hal ini, perlu adanya inovasi, solusi, dan tranformasi sistem yang dapat menjamin suplai yang cukup kepada profesional kesehatan untuk memenuhi kebutuhan masyarakat. Salah 
satu dari sekian banyak pilihan yang menjanjikan dalam inovasi tersebut adalah adanya IPE dalam pendidikan profesi kesehatan.

Interprofesional education (IPE) adalah suatu inovasi dalam konsep pendidikan profesi kesehatan. IPE merupakan suatu proses sekelompok mahasiswa atau profesi kesehatan yang memiliki perbedaan latar belakang profesi yang melakukan pembelajaran bersama dalam periode tertentu. Selanjutnya, mereka berinteraksi dan berkolaborasi dalam upaya promotif, preventif, kuratif, dan rehabilitatif dengan konsep kesehatan berbasis patients-centered-care. Konsep ini mengutamakan pasien, sedangkan tenaga kesehatan dituntut memberikan segala kemampuannya untuk pasien.

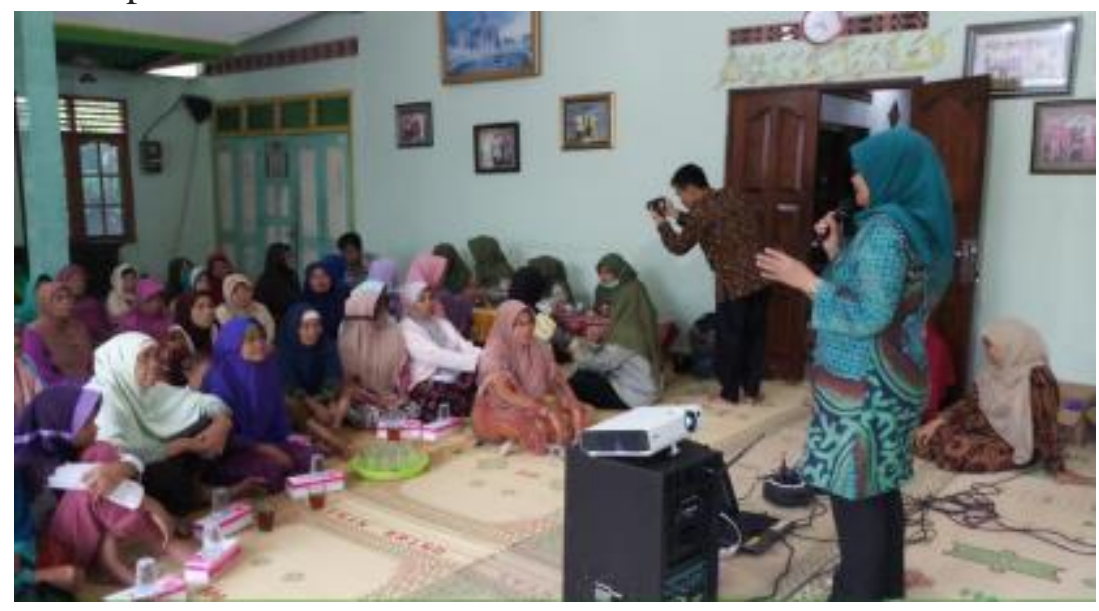

Gambar 1. Penyuluhan Hipertensi

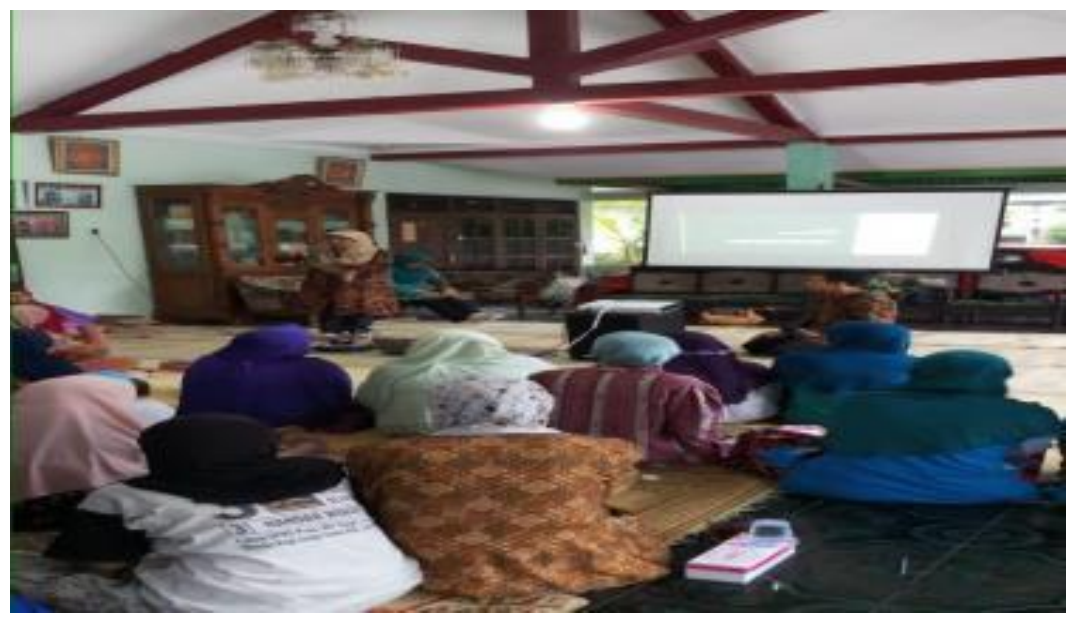

Gambar 2. Penyuluhan DM

Penerapan sistem IPE dalam dunia pendidikan kesehatan di Indonesia diharapkan mampu meningkatkan kualitas mahasiswa kesehatan. IPE diharapkan mampu meningkatkan kegiatan dalam Tri Dharma Perguruan Tinggi di Indonesia, yakni pendidikan, penelitian, dan pengabdian masyarakat berbasis pada kolaborasi. Hal ini bertujuan untuk melakukan upaya pembangunan kesehatan di Indonesia. Oleh karena itu, dengan IPE, tim kesehatan ke depannya terbiasa melakukan kolaborasi saat di tatanan pendidikan, pelayanan, maupundan pengabdian kepada masyarakat. 
IPE dalam dunia pendidikan profesi kesehatan melibatkan mahasiswa kesehatan dari berbagai profesi untuk saling belajar secara berdampingan. IPE menekankan kerja sama tim, memahami peran profesi yang lain, tanggung jawab, komunikasi, saling menghormati, dan memberikan kontribusi positif terhadap perkembangan ilmu pengetahuan. Salah satu terobosan yang bisa dilakukan adalah mengimplemetasikan IPE ke dalam kurikulum pendidikan profesi kesehatan.

Penyakit tentang hipertensi telah dijelaskan oleh Dr.Wiwik Kusumawati,M.Kes. Materi ini menjelaskan tentang penyebab hipertensi, obat-obat yang bisa diberikan, cara mencegah dan mengobatinya, dan penyebab dari hipertensi. Sementara materi tentang penyakit DM disampaikan oleh Dra. Salmah Orbayinah,M.Kes.,Apt. Materi DM menjelaskan penyakit DM, faktor-faktor penyebabnya, cara mencegah dan mengatasinya, dan cara mempertahankan agar kadar gula dalam darah tetap normal. Peserta sangat tertarik dan antusias mendengarkan penjelasan terbukti dengan banyaknya pertanyaan yang muncul. Di akhir sesi, kami memberikan umpan balik dengan memberikan pertanyaan kembali seputar IPE, hipertensi, dan DM. Dari jawaban yang diberikan, $90 \%$ peserta menunjukkan tingkat pemahaman yang baik.

Kegiatan dilanjutkan dengan pelatihan dan pengukuran tensi dan kadar gula darah kepada peserta yang hadir. Pelatihan dan pengukuran kadar gula darah dilaksanakan bekerja sama dengan tim TBM FKIK UMY.

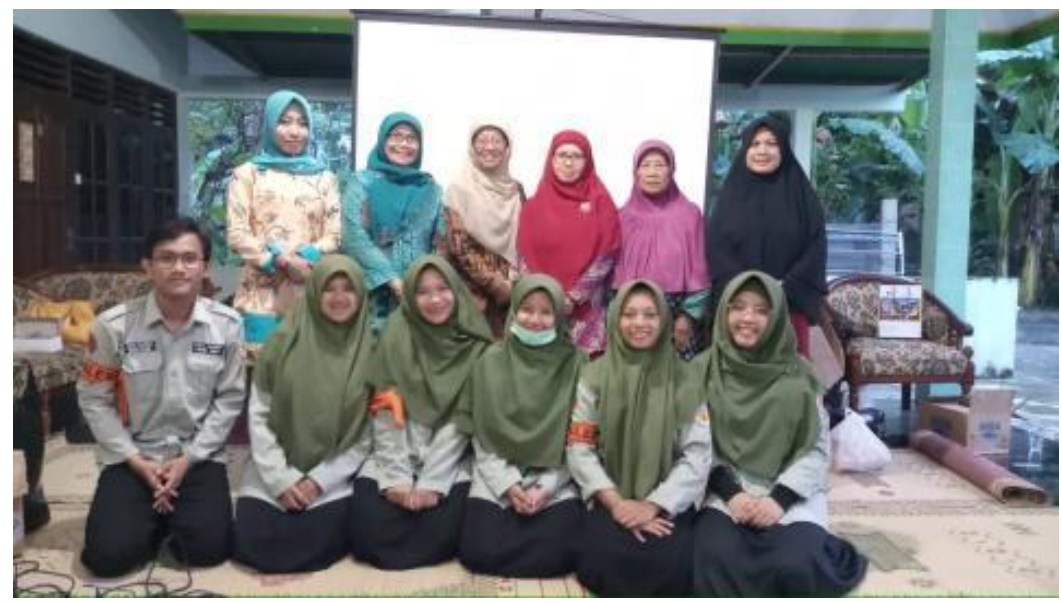

Gambar 3. Foto bersama Tim TBM FKIK UMY

Dari hasil pemeriksaan, terdapat 15 peserta dengan tensi tinggi dan 1 orang peserta dengan kada gula darah sangat tinggi. Hal ini menunjukkan bahwa penyuluhan tentang hipertensi dan DM masih sangat diperlukan. Penjelasan tentang senam DM juga dijelaskan kepada peserta. Senam DM ini sangat penting dilakukan sebagai salah satu pilar yang dapat menurunkan kadar gula dalam darah. Senam sebaiknya dilaksanakan setiap hari selama 30 menit.

Kegiatan dilanjutkan dengan pembentukan komunitas hipertensi dan DM, baik beranggotakan pendeita maupun nonpenderita. Komunitas ini bersifat mandiri dan diharapkan bisa meningkatkan kualitas hidup bagi anggotanya.

\section{Simpulan}

Terjadi peningkatan kesadaran peserta terhadap pentingnya perawatan yang komprehensif, peningkatan pemahaman tentang cara mencegah dan mengatasi penyakit hipertensi dan DM, 
terbentuknya komunitas peduli hipertensi dan DM di Desa Argorejo, Sedayu, Bantul yang berbasis pelayanan atau praktik Interprofessional Collaboration, dan peningkatan pemahaman gaya hidup sehat pada pasien hipertensi dan DM di Desa Argorejo, Sedayu, Bantul. Dari 48 peserta yang diukur tekanan darah dan kadar gula darahnya, 15 peserta bertekanan darah tinggi, 1 orang mempunyai kadar gula darah yang tinggi, dan selebihnya dinyatakan normal.

\section{Ucapan Terima Kasih}

Kami mengucapkan terima kasih kepada Pimpinan Aisyiyah Cabang Sedayu, masyarakat Desa Argorejo, Sedayu, Bantul, dan mahasiswa TBM Alert FKIK UMY.

\section{Daftar Pustaka}

Centre for the Advancement of Interprofessional Education (CAIPE). 2002. Interprofessional Education: A definition. London:CAIPE

Depkes RI. 2005. Pharmaceutical Care untuk Penyakit Diabetes Mellitus.Jakarta: Departemen Kesehatan Republik Indonesia

Dinkes DIY. 2012. Profil Kesehatan Provinsi Daerah Istimewa Yogyakarta 2011. Yogyakarta: Dinas Kesehatan DIY

Harini, M. 2008. Pengaruh Pelatihan Komunikasi dan Kolaborasi Terhadap Praktik Kolaborasi antara Dokter dan Perawat di Unit Perawatan Intensif Rumah Sakit Rajawali Bandung. (Tesis) Yogyakarta: Program Pasca Sarjana Universitas Gadjah Mada.

Kagan, S.H. 2010. Revisiting interdisciplinary teamwork in geriatric acute care. Geriatric nursing (NewYork,N.Y.), 31(2), pp.133-6. Available at: http://www.ncbi.nlm.nih.gov/pubmed/20381716 [Accessed April 6, 2012]

Perkeni. 2011. Konsensus Pengelolaan Diabetes Mellitus Tipe 2 di Indonesia. Jakarta: Perkumpulan Endokrinologi Indonesia

Priyanto. 2008. Farmakoterapi dan Terminologi medis. Yogyakarta: Leskonfi

Suyono, S.. 2011. Patofisiologi Diabetes Mellitus dalam buku Penatalaksanaan Diabetes Terpadu sebagai Panduan Penatalaksanaan Diabetes Mellitus bagi dokter maupun edukator diabetes. Jakarta: Fakultas Kedokteran Universitas Indonesia

Tandra, H. 2008. Segala Sesuatu Yang Harus Anda Ketahui Tentang- DIABETES. Jakarta: PT Gramedia Pustaka Utama

World Health Organization. 2010. Framework for Action on Interprofessional Education and Collaborative Practice. Geneva: WHO 